\title{
PARAGONIMOSIS IN THE CAJABAMBA AND CONDEBAMBA DISTRICTS, CAJAMARCA, PERU
}

\author{
William CORNEJO(1), Alina HUIZA(1,2), Yrma ESPINOZA(1,2), Pilar ALVA(1), Carlos SEVILLA(3) \& Wilson CENTURION(4)
}

\begin{abstract}
SUMMARY
Stool samples from 409 pre-school and school students, living in six villages of the Cajabamba and Condebamba districts, Cajamarca, Perú, were examined using wet preparations and Lumbreras' method, looking for Paragonimus eggs. Fecal and sputum samples from two children $(0.5 \%)$ of 6 and 8 year-old showed eggs of Paragonimus. One hundred and twenty freshwater crabs, Hypolobocera chilensis eigenmanni, were collected from the Condebamba valley and $21(17.5 \%)$ of them were infected with $P$. mexicanus (syn. P. peruvianus) metacercariae. Our results show the persistence of Paragonimus in human beings and in the main source of infection, the crabs.
\end{abstract}

KEYWORDS: Paragonimus sp.; Freshwater crab; Paragonimosis; Metacercariae.

\section{INTRODUCTION}

Paragonimosis is a zoonotic disease caused by the lung fluke belonging to genera Paragonimus, being Paragonimus mexicanus (synonymous $P$. peruvianus) the main species found in Peruvian paragonimosis cases $^{13}$. Human beings usually become infected by eating raw or partially cooked infected crabs. Hypolobocera chilensis eigenmanni, the main second intermediate host, is the freshwater crabs species involved in the transmission of paragonimosis in Perú ${ }^{6}$. Previous studies $^{2,12}$ have reported high prevalence rates of infections $(40-70 \%)$ among crabs with the larvae metacercariae of $P$. mexicanus.

The department of Cajamarca has been described as a main human

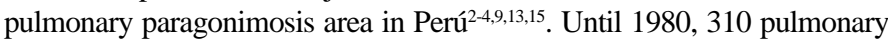
paragonimosis cases had been reported, most of them from the Condebamba valley in the department of Cajamarca (135 cases) ${ }^{4}$. The disease shows a spectrum of clinical manifestations ranging from asymptomatic individuals to patients with pulmonary disease, which may resemble tuberculosis. Many of these patients are treated as having tuberculosis.

From 1980 to date there is little information on paragonimosis in the Cajabamba and Condebamba districts. This study intends to determine the prevalence of human paragonimosis in pre-school and school children from the Condebamba valley and the prevalence of Paragonimus infection in crabs gathered from nearby streams.

\section{MATERIALS AND METHODS}

Four hundred nine stool samples were collected from pre-school and school children in May and October 1996. They came from 5 public schools and 1 day care center (DCC), randomly selected from various areas of the Cajabamba and Condebamba districts (Figure 1). Surveys were carried out so that the sample size in each school and the DCC was representative of the students enrolled in them. The age and sex distribution of the children is described in Table 1.

The individual stool sample was collected in a $30 \mathrm{ml}$ plastic or polystyrene (Teknopor ${ }^{\circledR}$ ) flask, containing a 10\% formaldehyde solution in saline. All samples were taken to the Parasitology Laboratory of the Instituto de Medicina Tropical "Daniel A. Carrión", where they were processed using the LUMBRERAS' method $^{5}$. The formalinized specimen was stirred and 10-20 $\mathrm{ml}$ of each suspension was strained through gauze into a conical sedimentation flask. After adding tap water, the mixture was allowed to stand for $5 \mathrm{~min}$, then $2 / 3$ of the supernatant fluid was decanted and the same wash procedure was repeated 2-3 times until a

Table 1

Age distribution of children surveyed in the Condebamba and Cajabamba districts, Peru

\begin{tabular}{cccc}
\hline $\begin{array}{c}\text { Age group } \\
\text { (years) }\end{array}$ & Male & $\begin{array}{c}\text { No. of children studied } \\
\text { Female }\end{array}$ & Total \\
\hline $3-5$ & 19 & 27 & 46 \\
$6-8$ & 46 & 66 & 112 \\
$9-11$ & 82 & 46 & 128 \\
$12-14$ & 50 & 41 & 91 \\
$15-18$ & 18 & 14 & 32 \\
\hline Total & 215 & 194 & 409 \\
\hline
\end{tabular}

(1) Departamento de Microbiología Médica, Facultad de Medicina, Universidad Nacional Mayor de San Marcos, Lima, Perú.

(2) Sección de Parasitología, Instituto de Medicina Tropical “Daniel A. Carrión”, Universidad Nacional Mayor de San Marcos, Lima, Perú.

(3) Licenciado en Tecnología Médica, Universidad Nacional Mayor de San Marcos, Lima, Perú.

(4) Hospital de Apoyo de Cajabamba, Cajamarca, Perú.

Correspondence to: William Cornejo, Departamento de Microbiología Médica, Universidad Nacional Mayor de San Marcos, Calle José Santos Chocano 199, C.P. 10138 Lima, Perú. 


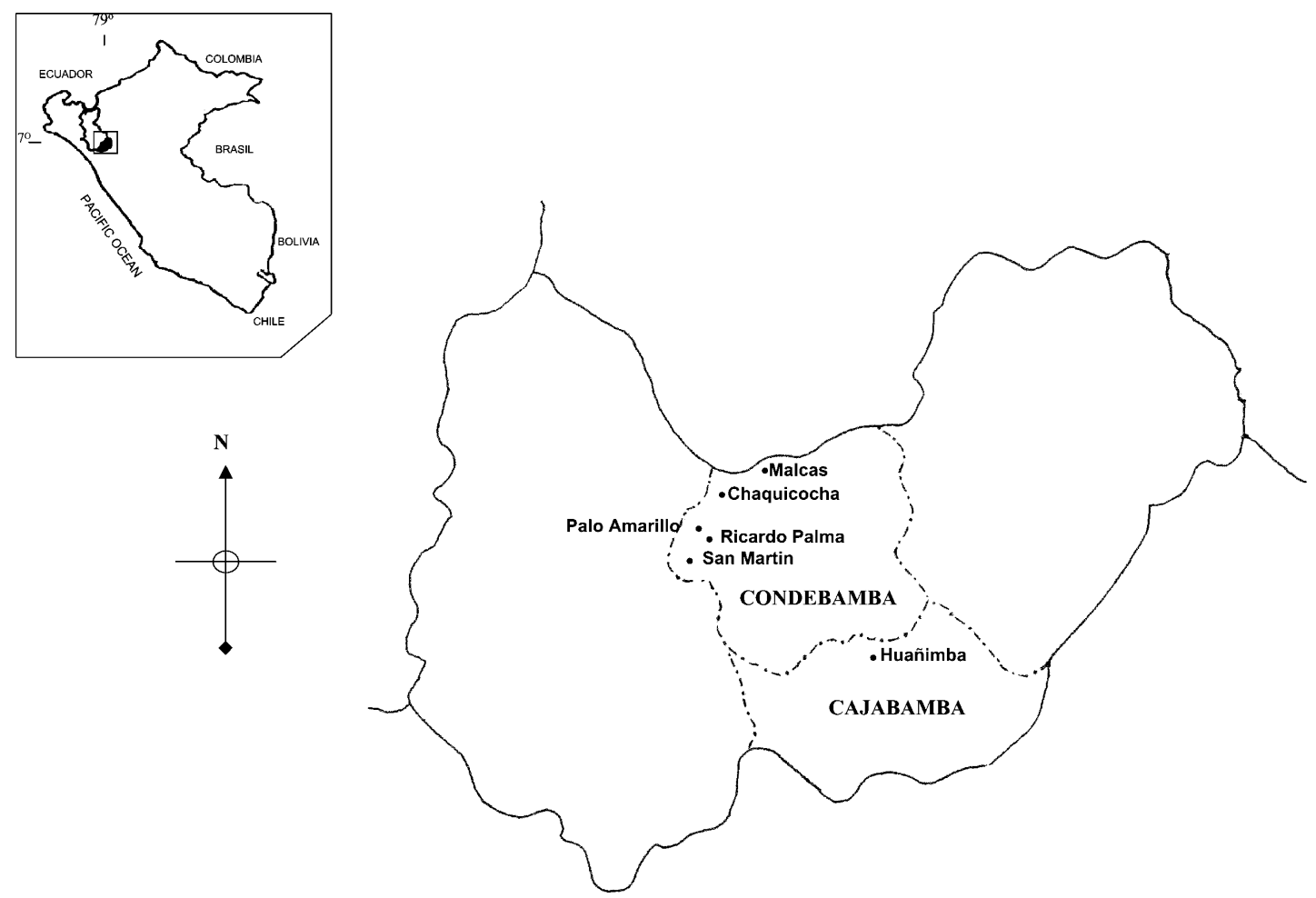

Fig. 1 - Province of Cajabamba showing the localities surveyed for paragonimosis

clarified supernatant was achieved. The sediment was finally stained by lugol and examined under the microscope for parasite eggs.

All the positive cases of Paragonimus eggs in stools were subjected to sputum and chest X-ray examination to confirm the diagnosis of paragonimosis. The sputum samples were dissolved in a $3 \%$ potassium hydroxide solution and centrifuged. The sediments were examined microscopically (40x magnification).

One hundred and twenty freshwater crabs were collected from small streams in areas belonging to the Condebamba valley. The collection was performed during the dry season, from May to October, 1996. Each crab was examined macroscopically, and the species, sex and size of shell were registered. The crabs were examined on site or were transported and examined at the laboratory.

\section{RESULTS}

We have identified eggs of $P$. mexicanus in 2 out of $409(0.5 \%)$ stool samples. The two male children ( 6 and 8 year-old) also had a positive sputum examination and abnormal chest X-ray films showing diffuse infiltrative lung lesions.

P. mexicanus metacercariae were identified according to MIYASAKI $\&$ ISHII $^{7}$ in 21 out of 120 crabs $(17.5 \%)$. The number of metacercariae per crab was 4.6. No significant difference was found between parasitized male $(57.1 \%)$ and female $(42.9 \%)$ crabs. There was no correlation between the number of parasitized crabs and their age according to the size of their shell. All infected crabs were identified as Hypolobocera chilensis eigenmanni ${ }^{6}$.

\section{DISCUSSION}

This study shows a low prevalence rate of Paragonimus infection among children of Condebamba valley. Reduction in prevalence may be the consequence of the health education campaigns aimed at reducing ingestion of raw or under-cooked crabs ${ }^{15}$. Changes in the habitat of natural hosts may also have reduced the transmission. In the examined streams, a smaller number of crabs were collected, as compared to previous years. Likewise, the snail species pointed out as first intermediate host was found in small numbers in these areas (data not shown) whereas a huge population was usually found in the past two decades. Further inquiry to know the nature of this change is necessary.

In an immunological survey for paragonimosis with an intradermal test (IDT) in the Condebamba valley, GRADOS et al. ${ }^{3}$ found a positive rate of $33.9 \%$ (54/159) among children and adults. Paragonimus eggs were detected in sputum in only 3 out of 29 examined persons $(10.3 \%)$. These results, obtained between 1965 and 1967, show a high prevalence of paragonimosis in this area in contrast with our recent finding that only 2 out of $77(2.6 \%)$ school children examined in the Condebamba valley were positive with IDT $^{1}$. Our present results may indicate that this prevalence is still going down. In addition, NAQUIRA et al.$^{8,9}$ made an immunological and parasitological survey for paragonimosis in elementary and high school students in two districts of Cajamarca. They found Paragonimus eggs in stools of 3 out of 68 (4.4\%) students in San 
Juan and 1 out of $168(0.6 \%)$ in Magdalena, while IDT was positive in $15.7 \%$ of the individuals in San Juan and $6.9 \%$ in Magdalena. Although the IDT using extract of Paragonimus is simple and reliable for screening patients, it cannot distinguish between present and past infection ${ }^{10,11}$ and it may have cross reaction with other trematode infections. A similar study was carried out by YOKOGAWA et al. ${ }^{15}$ in the San Juan and Magdalena areas, where they found positive IDT in only 10 out of 190 (5.2\%) children (Magdalena) and in 19 out of $203(9.3 \%)$ children in San Juan. Stool examination in both areas showed a prevalence rate of less than $2 \%$ for Paragonimus infection. All these data indicate that the prevalence of paragonimosis in the main endemic areas in Cajamarca is declining.

Prevalence of infection of the second intermediate host's population is still high (17.5\%) although this is a lower rate than those previously reported by CUBA et al. ${ }^{2}$ and TANTALEAN et al. ${ }^{12}: 43.9 \%$ and $72.4 \%$ for Pseudothelphusa chilensis (synonimous $H$. chilensis eigenmanni). These differences may be explained by ecological changes or seasonal variation. VIEIRA et al. ${ }^{14}$ explained the low rate of parasitized crabs in some areas of Ecuador by the depopulation of the definitive hosts due to hunting or destruction of the habitat of natural hosts, which are active reservoirs of the infection. The rate of crabs infected with $P$. mexicanus still represents an important source of transmission, since the infection intensity was 4.6 metacercariae per infected crab. The incidence of paragonimosis in the Condebamba valley has been mainly associated with the consumption of infected crabs, particularly with the consumption of raw crab with lemon juice ("ceviche"), a very effective way of acquiring the infection ${ }^{13}$.

In summary, the detection of $P$. mexicanus infection in two boys and in freshwater crabs indicate persistence of paragonimosis in the endemic area of Cajamarca. The infection may be underdiagnosed, since affected people have limited access to medical aid. Moreover, patients with haemoptysis due to pulmonary paragonimosis are misdiagnosed and treated as tuberculosis. Additional studies using immunological methods must be done to establish the real situation of paragonimosis in Cajamarca, as well as the factors that condition it.

\section{RESUMO}

\section{Paragonimíase nos distritos de Cajabamba e Condebamba, Cajamarca, Peru}

As amostras de fezes de 409 pré-escolares e escolares de 6 localidades dos distritos de Cajabamba e de Condebamba, departamento de Cajamarca, Peru, foram avaliados pelo método de Lumbreras na busca de ovos de Paragonimus sp.

Dois meninos $(0,5 \%)$, de 6 a 8 anos de idade, revelaram ovos de Paragonimus sp. nas suas fezes, bem como nas amostras de escarro. $\mathrm{O}$ exame radiográfico de tórax mostrou lesões pulmonares. Foram coletados 120 caranguejos de rio, Hypolobocera chilensis eigenmanni, no vale de Condebamba, encontrando-se 21 (17,5\%) infectados com metacercárias de $P$. mexicanus (sin. P. peruvianus). Nossos resultados revelam a persistencia de Paragonimus sp. na população na sua principal fonte de infecção, os caranguejos.

\section{ACKNOWLEDGEMENTS}

We are grateful to Dr. César Náquira for suggestions, Mr. Alejandro Medina for collaborating in obtaining the crabs and to CSI (Consejo Superior de Investigaciones/UNMSM/Lima. Proyecto 6010108) for finantial support.

\section{REFERENCES}

1. CORNEJO, W.; NAQUIRA, C.; ESPINOZA, Y. et al. - La paragonimosis en escolares del valle de Condebamba, Cajamarca-Perú. An. Fac. Med. (Lima), 60: 196-198, 1999

2. CUBA, C.; FERNANDEZ, E. \& MIRANDA, H. - Paragonimus y paragonimiasis en el norte peruano. Infección natural de Pseudothelphusa chilensis por metacercarias de Paragonimus, Braun, 1899. Rev. peru. Biol., 1: 128-135, 1974.

3. GRADOS, O.; CUBA, C.; MORALES, F. \& MAZABEL, T. - Epidemiología de la paragonimiasis en el Perú. Arch. peru. Pat. Clín., 26: 33-54, 1972.

4. IBAÑEZ, N. \& FERNANDEZ, V. - Actual state of paragonimiasis in Perú (1980). Bol. peru. Parasit., 2: 12-18, 1980.

5. LUMBRERAS, H.; CANTELLA, R. \& BURGOS, R. - Acerca de un procedimiento de sedimentación rápida para investigar huevos de Fasciola hepatica en las heces. Su evaluación y uso en el campo. Rev. méd. peru., 31: 167-174, 1964.

6. MAYTA, R. \& UYEMA, N. - Cangrejos de importancia sanitaria en el Perú. An. cient. Univ. nac. Agraria, 18: 75-81, 1980.

7. MIYASAKI, I. \& ISHII, Y. - Studies on the Mexican lung flukes, with special reference to a description of Paragonimus mexicanus sp. n. Jap. J. Parasit., 17: 445-453, 1968.

8. NAQUIRA, C.; DELGADO, E.; TANTALEAN, M.; NAQUIRA, F. \& ELLIOT, A. Prevalencia de enteroparásitos en escolares de los distritos de San Juan y Magdalena (Cajamarca) 1971. Rev. peru. Med. trop., 2: 34-41, 1973.

9. NAQUIRA, C.; DELGADO, E.; NAQUIRA, F.; ELLIOT, A. \& TANTALEAN, M. - La paragonimiasis en la población de los distritos de San Juan y Magdalena (Departamento de Cajamarca) 1971. Biota, 11: 23-33, 1976.

10. RAZAQUE, M.A.; MUTUM, S.S. \& SINGH, T.S. - Recurrent haemoptysis? Think of paragonimiasis. Trop. Doctor, 21: 153-155, 1991.

11. SINGH, T.S.; MUTUM, S.S. \& RAZAQUE, M.A. - Pulmonary paragonimiasis: clinical features, diagnosis and treatment of 39 cases in Manipur. Trans. roy. Soc. trop. Med. Hyg., 80: 967-971, 1986.

12. TANTALEAN, M.; HUIZA, A \& DELGADO, E. - La infección de cangrejos procedentes del valle de Condebamba (Cajamarca) por metacercarias de Paragonimus. Rev. peru. Biol., 1: 192-193, 1974.

13. TANTAlEAN, M. \& HUIZA, A. - Paragonimus y paragonimiasis en el Perú. Bol. Med. trop. "Daniel A. Carrión” (Lima), 5: 33-39, 1986.

14. VIEIRA, J. C.; BLANKESPOOR, H.D.; COOPER, P.J. \& GUDERIAN, R.H. Paragonimiasis in Ecuador: prevalence and geographical distribution of parasitisation of second intermediate hosts with Paragonimus mexicanus in Esmeraldas province. Trop. Med. Parasit., 43: 249-252, 1992.

15. YOKOGAWA, M.; INATOMI, S.; TSUJI, M. et al. - Pathobiological studies on paragonimiasis in Peru and Ecuador (56041013). Chiba University, 1983.

Received: 08 October 1999

Accepted: 03 July 2000. 